\title{
SELF INCRIMINATION BY FEDERAL GRAND JURY WITNESSES: UNIFORM PROTECTION ADVOCATED
}

FEDERAL grand jury investigations often conflict with the fifth amendment prohibition against compulsory self incrimination. ${ }^{1}$ Embodying historical opposition to coerced disclosure of one's own guilt, the fifth amendment subordinates the official quest for evidence to the individual's need for safeguards. ${ }^{2}$ The grand jury, on the other hand, provides the government its most effective forum for interrogating suspected offenders. ${ }^{3}$ Originally established to prevent unjustified prosecutions, ${ }^{4}$ it operates today in camera, under the supervision of a foreman, to call witnesses, assess information presented by the prosecutor, discover criminal activity and return indictments. ${ }^{5}$ Its inquiries and the fifth

1. "No person ... shall be compelled in any criminal case to be a witness against himself ...." U.S. Const. amend. V. A grand jury proceeding is a criminal case in terms of the fifth amendment privilege against self incrimination since the protection extends to any investigation in which a witness might incriminate himself. Counselman v. Hitchcock, 142 U.S. 547 (1892). See also 8 Wigmore, Evmence \$ 2252(1) (c) (3d ed. 1940) (hereinafter cited as WiGMoRE) ; Annot., 38 A.I.R.2d 225 (1954) (collecting cases illustrating situations in which the fifth amendment is applicable).

2. For discussion and history of the privilege against self incrimination, see Twining v. New Jersey, 211 U.S. 78 (1908); Corwin, The Supreme Court's Construction of the Self-Incrimination Clause, 29 MrcH. L. Rzv. 1, 191 (1930); Morgan, The Privilege Against Self-Incrimination, 34 MrNn. L. Rev. 1 (1949); Pittman, The Colonial and Constitutional History of the Privilege Against Self-Incrimination in America, 21 VA. L. REv. 763 (1935). See also \& WIGMrore $\$ \$ 2250-51$ and cases cited.

"The duty [to testify before the grand jury], so onerous at times, yet so necessary to the administration of justice according to the forms and modes established in our system of government ... is subject to mitigation in exceptional circumstances; there is a constitutional exemption ... from being a witness against oneself .... But, aside from [this] exception ... the witness is bound not only to attend but to tell what he knows in answer to questions framed for the purpose of bringing out the truth of the matter under inquiry." Blair v. United States, 250 U.S. 273, 281-82 (1919).

3. For cases in which elaborate grand jury interrogation disclosed information leading to conviction, see United States v. Klein, 124 F. Supp. 476 (S.D.N.Y. 1954), aff'd, 247 F.2d 908 (2d Cir. 1957) ; cases cited note 19 infra.

4. "No person shall be held to answer for a capital, or otherwise infamous crime, unless on a presentment or indictment of a Grand Jury . . ." U.S. CoNST. amend. V. For a history of the grand jury system and its early role as guardian against capricious indictments, see 1 Holdsworth, A HISTORY OF ENGLish LAw 321-23 (7th ed. 1956); McClintock, Indictment by a Grand Jury, 26 MINN. L. Rev. 153, 156-69 (1942) ; Younger, The Grand Jury Under Attack, 46 J. CRIM. L., C. \& P.S. 26, 214 (1955).

5. FED. R. CRIM. P. 6. The grand jury is summoned and impaneled by a judge of a United States District Court. Its function is not only to determine whether an accused should stand trial but also to conduct a general investigation into criminal activity within the jurisdiction of the court. For the prosecutor's role, see Mellott, Model Charge to the Grand Jury, 21 OrLA. B.A.J. 1265 (1950). See, generally, Wallace v. Hunter, 149 F.2d 59 (10th Cir. 1945); Gold, Privilege Against Self-Incrimination in Federal Grand Jury Procedings, 24 TEMr. L.Q. 395 (1951) ; Note, The Grand Jury-Its Investigatory Powers and Limitations, 37 MinN. L. Rev. 586 (1953). 
amendment have been accommodated by granting witnesses either complete immunity from questioning ${ }^{6}$ or a privilege to refrain from self incrimination by invoking the amendment as needed. ${ }^{7}$ Uneven treatment occurs because courts seeking a proper definition of constitutional protection in this context have until recently adopted two different rules applicable to criminal trials. ${ }^{8}$

Implementation of the fifth amendment at trial rests on a formal distinction between the status of witness and defendant. A witness must take the stand ${ }^{9}$ but may avoid self incrimination by claiming the constitutional privilege. ${ }^{10}$

6. See United States v. Lawn, 115 F. Supp. 674 (S.D.N.Y. 1953), discussed note 17 infra; see also United States v. Edgerton, 80 Fed. 374 (D. Mont. 1897).

7. See, e.g., United States v. Scully, 225 F.2d 113 (2d Cir.), cert. denied, 350 U.S. 897 (1955); cases cited note 19 infra. For cases refusing to grant immunity from grand jury questioning to witnesses, see O'Connell v. United States, $40 \mathrm{~F} .2 \mathrm{~d} 201,205$ (2d Cir. 1930) ("mere summoning of a witness before the grand jury gives no basis for the assumption that his constitutional privilege will be impaired") ; United States v. Kimball, 117 Fed. 156, 163 (C.C.S.D.N.Y. 1902) (since a witness cannot claim his privilege until he has been sworn, the constitutional provision cannot be violated until that time); United States v. Manno, 118 F. Supp. 511, 516 (N.D. I11. 1954) (fifth amendment does not prevent individual from being called to testify before grand jury at which time he makes his election to testify or not). See also United States v. Monia, 317 U.S. 424, 433 (1943) (dissenting opinion) (privilege is to withhold answers, not to limit the range of public inquiry). But see cases cited notes 16-17 infra.

8. See notes 17, 19 infra analyzing application of trial court distinctions in grand jury proceedings. But see United States v. Scully, supra note 7, at 115 (criticizing analogy drawn between trial and grand jury as unsound).

9. Witnesses have long been required by statute to appear and testify before a federal petit jury. Act of Feb. 26,1853 , c. $80, \S 3,10$ Stat. 161, 169. This section is embodied in the compulsory process provision of FED. R. CRIN. P. 17.

10. 8 WIGMORE $\$ 2252$, at 324. The scope of the protection has been broadly defined in determining whether an answer may tend to incriminate. Thus, in the leading case of Hoffman v. United States, 341 U.S. 479, 488 (1951), the Court said: "In this setting it was not 'perfectly clear' from a careful consideration of all the circumstances in the case, that the witness is mistaken, and that the answer[s] cannot possibly have such tendency to incriminate," quoting Temple v. Commonwealth, 75 Va. 892, 898 (1881). A witness may claim the privilege even if his answer, although insufficient by itself to support a conviction, would furnish a link in the chain of evidence needed to prosecute the claimant. Blau v. United States, 340 U.S. 159 (1950).

The Hoffman test has been expanded by the Third Circuit: "It is enough (1) that the trial court be shown by argument how conceivably a prosecutor, building on the seemingly harmless answer, might proceed step by step to link the witness with some crime against the United States, and (2) that this suggested course and scheme of linkage not seem incredible in the circumstances of the particular case." United States v. Coffey, 198 F.2d 438, 440 (3d Cir. 1952). See also Emspak v. United States, 349 U.S. 190, 198 (1955). Because of the extensive criminal liability imposed by the Federal Conspiracy Act, 18 U.S.C. $\S 371$ (1952), and the multitude of offenses subject to prosecution under such pervasive statutes as the Internal Revenue Code, witnesses will have no difficulty in establishing the possiblity of self incrimination. See, e.g., United States v. Courtney, 236 F.2d 921 (2d Cir. 1956), 8 Srracuse L. Rev. 303 (1957).

For discussion of what constitutes an incriminating answer, see UNIFORM RULES of EVIDENCE rule 24 (1953) (hereinafter cited at UNIF. R. EvID.) ; 8 WIGMORE $\$ \$ 2260-61$; Gold, supra note 5; Note, 70 HARv. L. REv. 1454, 1456 (1957). 
A defendant, if he desires, can testify in his own behalf under the federal enabling statute which removes his common-law disqualification for interest. ${ }^{11}$ An unwilling defendant may not be called to the stand, nor may the jury draw an unfavorable inference from his silence. ${ }^{12}$ If the accused submits to ex-

11. "In the trial of all persons charged with the commission of offenses against the United States and in all proceedings in courts martial and courts of inquiry in any State, District, Possession or Territory, the person charged shall, at his own request, be a competent witness. His failure to make such request shall not create any presumption against him." 18 U.S.C. $\$ 3481$ (1952). Under the original federal enabling statute, Act of March 16, 1878, c. 37, 20 Stat. 30, a defendant was competent at his own request "but not otherwise." Although these words were deleted, the statute was rewritten "without change of substance." H.R. REP. No. 304, 80th Cong., 1st Sess. A168 (1947). The evident effect of the statute is to forbid calling of the accused by the prosecution. 8 WIGMORE $\$ 2268$, at 393; see United States v. Housing Foundation, Inc., 176 F.2d 665, 666 (3d Cir. 1949) (defendant may not be called to testify concerning a codefendant); Wolfson v. United States, 101 Fed. 430, 436 (5th Cir. 1900) (improper for the government to call a defendant to the stand without a request on his part to testify) ; cf. People v. Talle, 111 Cal. App. 2d 650, 664, 245 P.2d 633, 641 (1952) (commonlaw incompetency remains unless defendant requests the privilege of testifying under state enabling statute).

The privilege against self incrimination was fully recognized by 1685 . \& WIGMroRE $\S$ 2250 , at 298,300 . Until that time, a willing defendant could be sworn as a competent witness; but, reflecting the principle recently established in civil cases, it was then held that a defendant could not be sworn and had no standing as a witness. This common-law rule of incompetency rested upon the assumption that self-interest would induce a party to a civil or criminal proceeding to perjure himself. 2 WrGMoRe $\$ \S 575$, at $684-85,576$. Nonetheless, the practice of overtly questioning an unsworn defendant at trial did not cease until the early eighteenth century. \& WIGMrORE $\$ 2250$, at 298,300 . Because a defendant was not allowed counsel in treason cases until 1695,7 WrLI. 3 , c. 3 , or in felony cases until 1836, $6 \& 7 \mathrm{WIII} .4$, c. 114, he was permitted to plead his case orally and engage in argument with the court and prosecution. Thus, he was virtually compelled to answer the case against him, for if the accused failed to make an effective defense, his guilt would be inferred. Williams, The Proof of Gunt 41 (1955). A defendant in United States courts was not forced into this dilemma since he has always had the right to employ counsel at trial. 18 U.S.C. $\$ 563$ (1951), derived from the Act of April 30, 1790, c. 9, 1 STAT. 118. If he could not afford counsel, however, the effect was the same as the English rule. Originally, in some American state jurisdictions in which the defendant was incompetent, he was allowed to make unsworn statements. The practice still continues in Georgia, the only state that has not enacted an enabling statute. GA. CoDE ANN. $\$ \$ 38-415,-416$ (Supp. 1955).

The constitutional right to refrain from giving self-incriminatory answers includes defendants since they are now competent to testify, even though at the time of the adoption of the amendment they were not, and hence their need of the protection could not have been contemplated. United States v. Kimball, 117 Fed. 156, 160 (C.C.S.D.N.Y. 1902) (dictum) ; Corwin, supra note 2, at 12. But see Powell v. United States, 226 F.2d 269, 274 (D.C. Cir. 1955) (court incorrectly states that the privilege as applied to witnesses is derived from protection designed primarily for the accused).

12. 18 U.S.C. $\$ 3481$ (1952), quoted at note 11 supra. "The purpose of the law was to make defendants competent witnesses, but at the same time preserve to them the right to remain silent without prejudice." Wolfson v. United States, supra note 11, at 436. See also United States v. Scully, 225 F. $2 \mathrm{~d} 113,115$ (2d Cir. 1955) ; Dunmore, Inference From Clain of Prizilege by Accused, 3 J. CrIM. L. \& CRIMunoL 770 (1913).

In at least one federal case, conviction was reversed because one defendant had been 
amination, however, he will generally be held to have waived his fifth amendment rights in that proceeding. ${ }^{13}$

Although case law is currently in a state of transition, ${ }^{14}$ the weight of precedent requires, by analogy to trial procedure, that status also determines rights before a federal grand jury. ${ }^{15}$ Persons under formal criminal process, termed de jure defendants, therefore enjoy immunity from interrogation which must be affirmatively waived. ${ }^{16}$ Absent notice, understanding and voluntary

called to testify concerning a codefendant. United States v. Housing Foundation, Inc., supra note 11, at 666 . Granting a defendant the right not to be questioned has been criticized as an unwarranted extension of the privilege against self incrimination. See WiLLIAMs $o p$. cit. supra note 11 , at c. 3 .

Neither the prosecutor nor the court may comment to the jury on the defendant's refusal to take the stand. For collections of cases, see 8 WIGMrore $\$ 2272$; 18 U.S.C.A. at 337 (1951). A different rule has been suggested. "If an accused in a criminal action does not testify, counsel may comment upon accused's failure to testify, and the trier of fact may draw all reasonable inferences therefrom." UNIF. R. Evid. 23(4) and comment. Some states have adopted this practice. See, e.g., State v. Baker, $115 \mathrm{Vt}$. 94, 53 A.2d 53 (1947) (collecting authorities). See also note 28 infra and accompanying text. The English enabling act forbids comment by the prosecutor but not by the court. See Queen v. Rhodes, [1899] 1 Q.B. 77 (1898). See also Corwin, supra note 2 , at 205 .

13. Since any relevant fact asserted by a defendant who voluntarily takes the stand might tend to incriminate him, his offer of testimony upon any fact is a constructive waiver of fifth amendment protection as to every other relevant fact because of the necessary connection between them a11. 8 WIGMORE $\$ 2276(2)$ (collecting cases). A more restricted view found in a few state statutes refuses to extend waiver to criminal acts other than the one precisely charged. $I d$. at 448 . For the doctrine of waiver as applied to witnesses, see notes 39-40 infra.

14. See United States v. Klein, 247 F.2d 908 (2d Cir. 1957), cert. denied, 355 U.S. 924 (1958) (sole test of fifth amendment protection before grand jury is whether testimony was freely given); United States v. Scully, 225 F.2d 113 (2d Cir.), cert. denied, 350 U.S. 897 (1955) (rights of grand jury witnesses are not dependent upon status); United States v. Hoffa, 156 F. Supp. 495 (S.D.N.Y. 1957) (freedom from compulsion only criterion).

15. See cases cited notes 16-17 infra.

16. Two federal decisions have quashed an indictment on the ground that when interrogated, the grand jury witness was entitled to a trial defendant's right not to be questioned. See United States v. Lawn, 115 F. Supp. 674, 677 (S.D.N.Y. 1953) (de jure defendant); United States v. Edgerton, 80 Fed. 374 (D. Mont. 1897) (de facto defendant), both discussed at note 17 infra. Many cases have stated in dicta that a de jure defendant may not be questioned. See, e.g., Mulloney v. United States, 79 F.2d 566, 578-79 (1st Cir. 1935) (indictment invalid if de jure defendant called before grand jury); United States v. Grossman, 154 F. Supp. 813, 816-17 (D.N.J. 1957) (de jure defendant cannot be called to testify) ; United States v. Miller, 80 F. Supp. 979, 981-82 (E.D. Pa. 1948) (de jurc defendant may be interrogated only after he is informed of and has waived his right not to be questioned). Cf. UNIF. R. EvID. 23(1) (accused in a "criminal proceeding" may not be questioned). The absence of direct holdings is not indicative of the widespread acceptance of the rule since most prosecutors make it a practice not to call de jure defendants, thereby obviating court tests. See United States v. Scully, 225 F.2d 113, 116 (2d Cir. 1955). But see United States v. Kimball, 117 Fed. 156, 162 (C.C.S.D.N.Y. 1902) (status as de jure defendant only one element in determining if testimony compelled).

For the definition of de jutre defendant, see Virginia v. Paul, 148 U.S. 107, 119-21 (1893) 
surrender of the right not to be questioned, if a de jure defendant testifies, a subsequent indictment may be quashed or his incriminating admissions excluded at trial. ${ }^{17}$ In contrast, the grand jury may examine and validly indict

(under indictment, information or complaint); United States v. Kimball, supra at 162 (arrested and held under any legal process); United States v. Grossman, supra at 816 (same) ; United States v. Brown, 24 Fed. Cas. 1273, No. 14671 (D. Ore. 1871) (no one is a defendant until some distinct action is brought against him).

17. United States v. Lawn, supra note 16. This is the first federal case since 1897 to quash an indictment because of a violation of the privilege against self incrimination in the grand jury room. Relying upon dicta in earlier cases, see note 16 supra, the court found that Lawn, against whom a criminal information had been filed, was a de jure defendant entitled to immunity from questioning. Calling him to the stand without his request to testify and without informing him of his constitutional rights therefore vitiated the indictment. The court exercised the "inherent power, in its discretion, to dismiss indictments obtained in violation of the rights of defendants." $115 \mathrm{~F}$. Supp. at 678 , citing Mulloney v. United States, supra note 16; United States v. Miller, ibid; United States v. Kimball, ibid. In line with prior authority on the status distinction, Lazon nevertheless had scant precedent for the sanction applied. See 8 W IGMORE $\$ 2252$, at $325-26$ n.12. Although the trial judge's charge to the jury in Mulloney indicated that an indictment based solely upon the testimony of a de jure defendant could be quashed absent a request to testify, the appellate court explicitly approved only the portion of the charge directing that as a matter of law, Mulloney was not a de jure defendant before the grand jury. Mulloney $\mathrm{v}$. United States, supra note 16, at 579. Neither Kimball nor Miller indicate what effect calling a de jutre defendant to the stand without his request would have. The court in Larom did not cite United States v. Edgerton, supra note 16, the only other reported federal case quashing an indictment obtained in violation of the fifth amendment privilege, perhaps because Edgerton had not previously been followed. See note 19 infra.

A number of state courts have quashed indictments of de jutre defendants called to testify even though in some cases they had been told of their privilege against self incrimination. See Culbreath v. State, 22 Ala. App. 143, 113 So. 465 (1927) (witness informed); People v. Cochran, 313 Ill. 508, 145 N.E. 207 (1924) (same) ; People v. Singer, 5 N.Y. Crim. 1 (18S6) (same); Commonwealth v. Bane, 39 Pa. D. \& C. 664 (1940) (same). See also Boone v. People, 148 Ill. 440, 36 N.E. 99 (1894) (witness not informed); Taylor v. Commonwealth, 274 Ky. 51, 118 S.W.2d 140 (1938) (same); State v. Corteau, 198 Minn. 433, 270 N.W. 144 (1936) (same; the grand jury returning no indictment, a prosecutor's subsequent information based upon testimony illegally elicited in the grand jury set aside).

Vindicating constitutional rights by quashing an indictment recognizes that fifth amendment protection not only operates as an exclusion of illegally obtained evidence, see Bram v. United States, 168 U.S. 532, 542 (1897); In re Fried, 161 F.2d 453 (2d Cir. 1947), 56 Y YLE L.J. 1076, but also protects a defendant against conviction by preventing a trial upon the indictment, cf. Wood v. United States, 128 F.2d 265, 268 (D.C. Cir. 1942) ; \& WIGMrore $\$ 2266$. Despite the absence of precedent and assuming a violation of constitutional rights, the sanction applied in Lazen seems proper since the motion to quash was made prior to trial. The grand jury proceeding is designed in part to prevent unjustified prosecutions, see note 4 supra, and prosecution appears unjustified when indictment was obtained through violation of constitutional rights.

Once trial has been held, the injury of unwarranted subjection to prosecution has been inflicted. Given a fair trial in which evidence obtained in violation of constitutional rights was excluded, the defendant has been accorded adequate fifth amendment protection. See United States v. Garnes, 156 F. Supp. 467 (S.D.N.Y. 1957) (affirming the conviction of a witness who had given involuntary statements to the grand jury). "[T] he suppression 
all other witnesses without informing them of their constitutional privilege. ${ }^{18}$

Distinctions based on status have created an incongruous grand jury witness, the de facto defendant who, though not formally accused, is marked for prosecution. Functionally indistinguishable from a de jure defendant, he enjoys

at the trial of her testimony before the grand jury secured to her the full constitutional protection to which she was entitled." Id. at 469-70. A fair trial cured whatever defects were present in the indictment even though it might have been invalidated had the objection been timely. Id. at $470-71$.

In addition to quashing the indictment, the court in Lazm ordered the evidence produced by the defendants in violation of their fifth amendment privilege suppressed and returned, thus also applying the rule of Weeks v. United States, 232 U.S. 383 (1914), discussed note 45 infra. For the subsequent history of this portion of the decision, see United States v. Giglio, 16 F.R.D. 268 (S.D.N.Y. 1954); United States v. Giglio, 232 F.2d 589 (2d Cir. 1956), aff'd sub nom. Lawn v. United States, 355 U.S. 339 (1958) (upholding a subsequent reindictment and conviction upon failure to show that the suppressed testimony had been used in violation of the court order in the initial Lazen decision). See also N.Y. Times, April 18, 1958, p. 48, col. 1 (indicating that the "tainted" evidence had been used). For further discussion of Lazon, see notes 29,31 and 41 infra.

A third basis for quashing an indictment exists. If a statute granting immunity from prosecution based upon pre-trial testimony applies to the criminal activity under investigation and to the grand jury proceeding in which the witness' testimony was compelled, prosecution may be barred. See United States v. Goldman, 28 F.2d 424, 432-36 (D. Conn. 1928) (immunity from prosecution under National Prohibition Act as result of testimony given before grand jury); United States v. Moore, 15 F.2d 593, 594 (D. Ore. 1926) (same) ; United States v. Pardue, 294 Fed. 543, 548 (S.D. Tex. 1923) (immunity under Federal Trade Commission Act); cf. United States v. Monia, 317 U.S. 424 (1943) (immunity under Sherman Act); United States v. Andolschek, 142 F.2d 503 (2d Cir. 1944) (immunity under Internal Revenue Code). See 8 WIGMoRE $\$ 2282(3)$; Annot., 38 A.L.R.2d 225, 295-315 (1954), for discussion and collection of cases. Immunity could not have been claimed in Lazen, for no statute was applicable to the offense charged.

18. The duty of witnesses to appear and testify before a grand jury was recognized by the Act of Feb. 26, 1853, c. 80, \& 3, 10 STAT. 169. This section, together with provision for compulsory process, is embodied in FED. R. CRIM. P. 17. For application and discussion of the statute, see Blair v. United States, 250 U.S. 273, 280-82 (1919).

Apprising a witness of his privilege against self incrimination is not a prerequsite to a valid indictment. United States v. Scully, 225 F.2d 113 (2d Cir.), cert. denied, 350 U.S. 897 (1955) (de facto defendant before grand jury); Pulford v. United States, 155 F.2d 944 (6th Cir. 1946) ("mere" witness) ; United States v. Garnes, supra note 17 (de facto defendant); United States v. Haas, 126 F. Supp. 817 (S.D.N.Y. 1954) (same). But see United States v. Grossman, 154 F. Supp. 813, 816 (D.N.J. 1957) (indicating that a valid indictment may not be returned against a de facto defendant unless he was warned) ; United States v. Bell, 81 Fed. 830, 838 (C.C.W.D. Tenn. 1897) (conviction for perjury before pension examiner reversed because defendant had been manifestly ignorant of his rights); cf. United States v. Garnes, supra note 17 (exclusion of involuntary admissions at trial remedies failure to warn).

A witness was held not entitled to warning in the following cases: Powers v. United States, 223 U.S. 303, 313 (1912) (preliminary hearing); Wilson v. United States, 162 U.S. 613, 623 (1896) (interrogation by commissioner); United States v. Block, 88 F.2d 618, 620 (2d Cir. 1937) (trial). However, FED. R. CRIM. P. 5(b) now requires a warning in any hearing before a United States commissioner. For a collection of state cases sustaining the indictments of witnesses and de facto defendants who were not advised of their privilege against self incrimination, see Annot., 38 A.L.R.2d 225, 277-82 (1954). 
only the protection of an unimplicated witness and must submit to interrogation without apprisal of the charge pending against him or of his fifth amendment rights. ${ }^{10}$ The prosecutor can take advantage of this anomalous treatment by deferring formal charge, summoning a de facto defendant before the grand jury and seeking disclosures which ensure indictment and may be used at trial. ${ }^{20}$ The anomaly is heightened by the de facto defendant's relative lack of protection, since formal charge makes the de jure accused aware of the danger of self incrimination and the need for counsel. ${ }^{21}$ On the other hand, by refusing de facto de-

19. In each of the following cases, although the defendant when called before the grand jury had not been formally charged, the prosecutor intended to proceed against him at trial. Despite the already intended prosecution, grand jury interrogation was approved without defendant's having requested it since no charge had been preferred. United States v. Klein, 247 F.2d 908 (2d Cir. 1957), cert. denied, 355 U.S. 924 (1958) (prosecutor had information implicating defendants); United States v. Scully, supra note 18, at 115 (same); Mulloney v. United States, 79 F.2d 566, 579-80 (1st Cir. 1935) (witness previously indicted but indictment lapsed); United States v. Hirsch, 74 F.2d 215, 217, 219 (2d Cir. 1934) (Post Office Department had issued fraud order naming defendants) ; O'Connell v. United States, 40 F.2d 201, 205-06 (2d Cir. 1930) (defendant's activities had been subject of grand jury investigation) ; United States v. Price, 163 Fed. 904 (C.C.S.D.N.Y. 1908) (U.S. Attorney General had requested indictment of defendants); cf. United States v. Wetmore, 218 Fed. 227, 233 (W.D. Pa 1914). The only reported federal case quashing an indictment of a de facto defendant is United States v. Edgerton, 80 Fed. 374 (D. Mont. 1897). The case has since either been distinguished on its facts, see United States v. Kimball, 117 Fed. 156, 167 (C.C.S.D.N.Y. 1902), or completely disregarded, perhaps as an unwarranted extension of Counselman v. Hitchcock, 142 U.S. 547 (1892). See United States v. Mangiaracina, 92 F. Supp. 96, 97 (W.D. Mo. 1950) ("the case . . has never been followed") ; United States v. Thomas, 49 F. Supp. 547, 550-51 (W.D. Ky. 1943) (same). But see Powell v. United States, 226 F.2d 269, 274 (D.C. Cir. 1955) ("serious constitutional question" whether a de facto defendant is subject to grand jury subpoena); $c f$. United States v. Minker, 350 U.S. 179, 196-97 (1956) (concurring opinion) (subpoena power of immigration officers should exclude potential defendants prior to deportation proceedings).

Most states allow de facto defendants to be questioned as ordinary witnesses. Annot., 38 A.L.R.2d 225, 277-82 (1954). In the following cases, however, state courts have quashed the indictments of de facto defendants called to testify before the grand jury. Culbreath $\mathrm{v}$. State, 22 Ala. App. 143, 113 So. 465 (1927); People v. Schneider, 133 Colo. App. 173, 292 P.2d 982 (1956) (de facto defendant must be warned of rights); State v. Allison, 116 Mont. 352, 153 P.2d 141 (1944) (same; coroner's jury). See also Jenkins v. State, 65 Ga. App. 16, 14 S.E.2d 594 (1941); State v. Rixon, 180 Minn. 573, 231 N.W. 217 (1930) ; State v. Caperton, 276 Mo. 314, 207 S.W. 795 (1918); People v. Seman, 174 Misc. 792, 21 N.X.S.2d 917 (Sup. Ct. 1940); State ex rel. Poach v. Sly, 63 S.D. 162, 257 N.W. 113 (1934).

20. See Powell v. United States, supra note 19, at 274 (criticizing such procedure). But see Maffie v. United States, 209 F.2d 225, 228-29 (1st Cir. 1954) (de facto defendant not guilty of contempt in refusing to return to the grand jury for further interrogation after he had indicated by invoking the fifth amendment that he would not answer any questions).

21. If the de jure defendant has been arrested upon a complaint, he will have been taken before a commissioner, informed of his privilege against self incrimination and given a reasonable opportunity to retain counsel. FED: R. CRrM. P. 17. Similarly, if an information has been filed, the accused will have been informed of the alleged offense with sufficient particularity to apprise him of the need for counsel. FED. R. CRIMr. P. 7. 
fendants immunity from questioning, courts have enhanced criminal investigation. If grand juries could not examine implicated parties, valuable sources of information would be foreclosed ${ }^{22}$ furthermore, quashing an indictment on the ground that a witness was a potential defendant would often be an illusory safeguard since reindictment could be readily obtained. ${ }^{23}$ Pre-trial interrogation is not uninhibited, however, for the fifth amendment prohibits compelling a person to be a witness against himself. ${ }^{24}$ Implementing this restriction, recent

22. "[A]ny other ruling would create grave problems in the administration of Grand Jury proceedings. Whenever a witness before the Grand Jury is subsequently indicted, it would be necessary to fathom the minds and the hearts of both the Grand Jurors and the United States Attorney, in order to determine whether at the time they were called the defendants were targets of the investigation and were marked for prosecution. Such is the rationale of the general Federal rule." United States v. Grossman, 154 F. Supp. 813, 817 (D.N.J. 1957) (refusing to extend the right not to be questioned to de facto defendants who had been apprised of their constitutional protection). See also United States v. Kimball, 117 Fed. 156, 168 (C.C.S.D.N.Y. 1902) :

"The theory of limiting grand juries to questioning persons disconnected with a ruined bank as to the cause thereof, in timorous expectation that a less remote search might chance to bring the persons guiltily concerned into the presence and under the examination of the jury, is not consonant with that vigor of inquiry that such exigencies demand. The persons whose duties converged at such bank would be those who should know, and it is of these persons that an investigating grand jury should inquire, not of those who, isolated from its affairs, would be presumed to have no knowledge. While much is due to the conservation of personal rights, the administration of justice should not be fettered by a sentimentality that would paralyze efficient action."

Because the grand jury can inquire into any area of supposed criminal activity, it may question a de facto defendant concerning activity which is not related to the crime for which he is marked for prosecution. Thus, the interrogation may involve matters to which the fifth amendment privilege could not be claimed because, for example, the statute of limitations has run, double jeopardy doctrine prevents a subsequent indictment, statutory immunity has been granted, see 8 WIGMORE $\$ \S 2279-83$, or because the questioning calls for nonincriminatory replies, see In re Black, 47 F.2d 542, 543 (2d Cir. 1931); United States v. Kimball, supra at 168.

23. An indictment will not be quashed because based upon insufficient or incompetent evidence. Costello v. United States, 350 U.S. 359 (1956), discussed note 31 infra. Moreover, Lawn v. United States, 355 U.S. 339 (1958), indicates that a reindictment is valid even if based upon evidence that was obtained through violation of fifth amendment rights during a prior grand jury hearing and would be inadmissable at trial. Thus, quashing an indictment of a de facto defendant would only delay but not prevent an ultimate trial on the merits.

24. In dealing with pre-arraignment interrogation of suspected offenders, the Supreme Court has either required that testimony be voluntary, see Wilson v. United States, 162 U.S. 613 (1896), or demanded strict compliance with the provision of FED. R. CKM. P. 5(a) forbidding "unnecessary" delay in bringing an arrested person before the nearest available commissioner, McNabb v. United States, 318 U.S. 332 (1943). There is no prohibition against orderly examination as such, and policemen enjoy a limited area of tolerance within which they may effectively operate. "Circumstances may justify a brief delay between arrest and arraignment, as for instance, where the story volunteered by the accused is susceptible of quick verification through third parties." Mallory v. United States, 354 U.S. 449, 455 (1957). The delay in Mallory amounted to compulsion, and the con- 
cases no longer equate a de facto defendant with a witness at trial and simply require that his, or any witness', testimony be voluntary. ${ }^{25}$

Courts could extend the test of volition to embrace all grand jury witnesses by abolishing the de jure defendant's immunity from interrogation. By its terms, the statute conferring the right to refrain from testifying applies only to a defendant at trial. ${ }^{26}$ Because, prior to the statute, defendants were not competent to take the stand, courts have never been required to decide whether freedom from questioning is part of the fifth amendment. ${ }^{27}$ The amendment might afford the same protection as the statute since mere resort to the privilege not to incriminate oneself could constitute evidence of guilt in the eyes of a trier of fact.28 When, however, not the imposition of criminal sanc-

fession obtained was a violation of the defendant's rights. His statements were not to be excluded, however, merely because obtained between arrest and arraignment. Thus, prior to trial, the privilege against self incrimination "is merely an option of refusal, not a prohibition of inquiry." \& WIgMrore $\$ 2268$, at 388. See also United States v. Mitchell, 322 U.S. 65 (1944) (confession legally obtained is not rendered inadmissable by a subsequent illegal detention). For general discussion, see Maguire, "Involuntary" Confessions, 31 TuL. L. Rev. 125 (1956).

25. See United States v. Klein, 247 F.2d 908 (2d Cir. 1957), cert. denied, 355 U.S. 924 (1958); United States v. Scully, 225 F.2d 113 (2d Cir. 1955), cert. denied, 350 U.S. 897 (1955) ; United States v. Hoffa, 156 F. Supp. 495 (S.D.N.Y. 1957) ; United States v. Grossman, 154 F. Supp. 813 (D.N.J. 1957).

26. 18 U.S.C. $\$ 3481$ (1952), quoted at note 11 supra. The statutory phrase, "courts of inquiry in any State," refers not to grand juries but to military proceedings prior to courts martial. See United States v. Shibley, 112 F. Supp. 734, 742 (S.D. Cal. 1953). Nevertheless, courts have at times implied that the statute is applicable to the grand jury. United States v. Kimball, 117 Fed. 156, 161 (C.C.S.D.N.Y. 1902) ; United States v. Lawn, 115 F. Supp. 674, 677 (S.D.N.Y. 1953) ; cf. Powers v. United States, 223 U.S. 303, 313 (1912) (statute applicable to preliminary hearing; now governed by FED. R. CRIM. P. 5).

27. Two cases deny that the Constitution affords a right not to be questioned. United States v. Kimball, supra note 26, at 160-61 (rights under the enabling statutes are not embodied in the Constitution; summoning a defendant before the jury and asking him to answer is not a per se violation of the Constitution, but at most of the law of the state); United States v. Price, 163 Fed. 904, 906-07 (S.D.N.Y. 1908) (immunity from questioning quite different from the rule regarding self incrimination; it is a statutory, not a constitutional privilege). See Reeder, Comment Upon Failure of Accused To Testify, 31 MIcH. L. REv. 40, 41 (1932); note 28 infra.

The only case purporting to hold that compelling a defendant at trial to take the stand and testify violates a constitutionally protected right is United States v. Housing Foundation, Inc., $176 \mathrm{~F} .2 \mathrm{~d}$ 665, 666 (3d Cir. 1949). But because the defendant was made to testify over his objection, this case is unclear on whether the mere summoning of a defendant to the stand would be a violation of the fifth amendment. See also Powell v. United States, 226 F.2d 269, 274 (D.C. Cir. 1955) ("[I]t would seem to be clear that a prosecutor could not even call to the stand in a criminal trial the person being tried") (dictum).

28. Calling an unwilling defendant to the stand at trial could only emphasize his refusal to reply, thus suggesting an inference of guilt which the jury could not be effectively prevented from drawing. Giving a defendant an option of admitting an incriminating fact or keeping silent and letting the same fact be inferred would accord him less fifth amendment protection at trial than a complete proscription of questioning. See 8 WIGMrorE $\$ \S 2268,2272-73$. See also United States v. Hamilton, 97 F. Supp. 123, 129 (S.D.W. Va. 
tions but the preliminary investigation of crime is undertaken, the existence of constitutional immunity from interrogation is doubtful. ${ }^{29}$ That the fifth amendment does not guarantee an unqualified right to remain silent without prejudice

1951) : "I am compelled to conclude that, because of the Court's omission in not rebuking government counsel for his remarks concerning [the defendant's] ... failure to testify, and the Court's further omission of any instruction to the jury to disregard the statements, [the defendant] ... was deprived of [his fifth amendment] ... privilege. As a result, he did not receive the fair and impartial trial which is guaranteed to every defendant." Thus, immunity from interrogation at trial is not based upon opposition to compulsory disclosure, for the option of refusal would be sufficient, but upon a desire to exclude the prejudicial effect of a claim of privilege. That the fifth amendment actually grants immunity is unclear, however. The Supreme Court has twice held that a state statute or constitutional provision permitting both comment upon and inference from the defendant's failure to take the stand does not violate due process of law under the fourteenth amendment. Adamson v. California, 332 U.S. 46 (1947) ; Twining v. New Jersey, 211 U.S. 78 (1908). The Court in Treining "assumed only for the purpose of discussion that what was done in the case at bar was an infringement of the privilege against self-incrimination. [It did] ... not intend, however, to lend any countenance to the truth of that assumption. . . . The authorities upon the question are in conflict." Id. at 114. But see the dissenting opinion of Justice Harlan. Ibid. A prominent commentator has said that fifth amendment immunity for defendants at trial is an open question. Corwin, supra note 2, at 201, 205.

In Adamson, the majority opinion assumed without deciding that permitting comment in a federal court on defendant's silence would violate the fifth amendment. 332 U.S. at 50. Justice Frankfurter, concurring, agreed that as part of the immunity granted, comment on the failure of the accused to take the stand is forbidden in federal prosecution. Id at 61. It is not clear, however, whether he was speaking of constitutional or statutory immunity. Justice Black, in dissent, interpreted the majority opinion as implying that the constitutional privilege did not, of itself, bar comment at a federal trial upon the defendant's failure to testify. $I d$. at 69 .

See also Woronoff v. Mallon, 222 N.Y. 456, 468, 119 N.E. 102, 106 (1918) (New York constitutional provision protecting against self incrimination does not grant immunity from examination). The American Law Institute and the National Conference of Commissioners on Uniform State Laws would permit both inference from and comment on defendant's silence. Moded Code of Evndence rule 201(3) (1942); UnIF. R. Evm. 23(4). But see Grunewald v. United States, 353 U.S. 391, 424 (1957) (allowing petit jury to consider claim of privilege made before the grand jury has "grave" constitutional overtones); Helton v. United States, 221 F.2d 338, 341, 342 (5th Cir. 1955) (violation of "spirit, if not the letter" of fifth amendment to admit testimony that defendant was given opportunity prior to trial to explain presence of marijuana and failed to do so); Note, 40 MinN. L. REv. 598 (1956).

When enabling statutes were first passed, one commentator believed them to be unconstitutional as effectively violating the privilege against self incrimination because the jury could not be prevented from drawing an inference of guilt from the defendant's failure to exercise his right to testify. See Maury, Validity of Statutes Authorising the Accused To Testify, 14 Ar. L. REv. 753, 762-63 (1880). For discussion and collection of cases determining the constitutionality of statutes authorizing comment on failure to testify, see Note, 57 YaLe L.J. 145 (1947). See also 8 WIGMroRE $\$$ 2272-73; Rattner, Consequenics of Exercising the Privilege Against Self-Incrimination, 24 U. CEI. L. REv. 472 (1957).

29. See United States v. Scully, 225 F.2d 113 (2d Cir. 1955) (policy underlying prohibition of inference from claim of privilege at trial has no application to inquisitorial proceedings of grand jury). See also Costello v. United States, 350 U.S. 359 (1956), discussed note 31 infra (grand jury may indict on merest scintilla of evidence) ; United States v. Garnes, 156 F. Supp. 467, 470 (S.D.N.Y. 1957) (grand jury not governed by application of 
is demonstrated by the inferences which juries in civil cases may draw from a claim of the privilege. ${ }^{30}$

same rules that operate at trial; to provide otherwise would transform the grand jury's investigation into a full preliminary trial to which defendants are not entitled); Note, 65 YALE L.J. 390 (1956) ; of. State v. Kemp, 126 Conn. 60, 72-74, 9 A.2d 63, 69-70 (1939) (defendant's contention that he was prejudiced before the grand jury by his claim of privilege rejected).

Currently, if a defendant does not take the stand at trial, the fact that he failed to testify at a preliminary or other prior examination is not admissable. 8 WIGMoRe $\S$ $2272 a$, at 418 ; cf. Helton v. United States, supra note 28 . If, however, the defendant elects to take the stand, the prosecutor may attempt to introduce a prior claim of the privilege in order to impeach. Such evidence is admissible to discredit a defendant's veracity only if a prior claim is inconsistent with his testimony at trial. Grunewald v. United States, supra note 28 , at 418 (possible impermissible impact upon the jury would outweigh the probative value of the claim in discrediting defendant's testimony). The only cases subsequent to Grntuewald deciding the same question have held evidence of a prior claim of privilege inadmissible. United States v. Tomaiolo, 249 F.2d 683, 691 (2d Cir. 1957) (witness' refusal to answer grand jury questions not sufficiently inconsistent with trial testimony to merit admission) ; Travis v. United States, 247 F.2d 130, 133 (10th Cir. 1957) (questioning character witness as to defendant's claim of privilege during congressional hearing of insignificant probative value).

The decision in United States v. Lawn, 115 F. Supp. 674 (S.D.N.Y. 1953), see note 17 supra, quashing an indictment of a de jure defendant who had been called to testify, was implicitly based upon a desire to prevent a grand jury inference of guilt from invocation of the privilege. Under Lazen, a de jure defendant would apparently be able to ignore a grand jury subpoena or, if he did appear, would have to be informed of and exercise his right not to be questioned outside the presence of the grand jury. But nothing precludes the prosecutor from bringing to the grand jury's attention the fact that a witness has refused to testify or that he is already under legal process, thereby circumventing Lazis.

30. United States v. Mammoth Oil Co., 14 F.2d 705, 729 (8th Cir. 1926), aff'd, 275 U.S. 13, 52-53 (1927) (jury allowed to consider failure of defendant to testify in action to cancel lease on grounds of fraud and corruption). See Rattner, supra note 28 , at 476 \& n.16.

A private employer may fire his employees for invoking the fifth amendment. United Elec. Workers v. General Elec. Co., 127 F. Supp. 934, 937 (D.C. Cir. 1954) (employer may discharge employees for refusal to testify before congressional committee); see Odell v. Humble Oil \& Refining Co., 201 F.2d 123, 128 (10th Cir.), cert. denied, 345 U.S. 941 (1953). See Finkelhor \& Stockdale, The Professor and the Fifth Anendment, 16 U. PITr. L. Rev. 344 (1955); Horowitz, Legal Aspects of "Political Blacklisting" in the Entertainnent Industry, 29 So. CALIF. L. Rev. 263 (1956); Comment, Loyalty and Private Employment: The Right of Employers To Discharge Suspected Subversives, 62 Y ALE L.J. 954 (1953). It is not clear, however, whether a governmental employer may constitutionally consider invocation of the privilege in discharging an employee. See Slochower v. Board of Educ., 350 U.S. 551 (1956) ; The Supreme Court, 1955 Term, 70 HaRv. L. Rev. 83, 120 (1956) (violation of due process for the New York City Board of Education to discharge a college professor, pursuant to a New York state law, for invoking the fifth amendment before a Senate Committee without holding a hearing as to his fitness to remain on the faculty; the Court did not indicate whether a dismissal based solely upon invocation of the fifth amendment after a full hearing would be unconstitutional). Cf. Wieman v. Updegraff, 344 U.S. 183 (1952) (a state may not dismiss teachers for mere membership in an organization listed by the Attorney General as subversive) ; Bailey v. Richardson, 182 F.2d 46 (D.C. Cir. 1950), aff'd per curiam, 341 U.S. 918 (1951) (affirming dismissal 
Grand jury inference of probable guilt based in part on a claim of fifth amendment protection is a logical exercise of the investigative function. A grand jury is not bound by rules of evidence and may base an indictment upon rationally persuasive testimony that would be insufficient or incompetent at trial. $^{31}$ Invocation of the privilege, though compatible with innocence, has sufficient probative value to merit consideration in determining whether an accused should stand trial. ${ }^{32}$ Extrinsic implicating evidence coupled with the

of a federal employee although at her hearing the employee could not cross-examine adverse witnesses); Rattner, supra note 28 , at 511.

31. Costello v. United States, 350 U.S. 359 (1956). If indictments were open to challenge on the ground of incompetent or inadequate evidence, a "preliminary trial" to determine the sufficiency and admissibility of evidence would be necessary. "An indictment returned by a legally constituted and unbiased grand jury, like an information drawn by the prosecutor, if valid on its face, is enough to call for trial of the charge on the merits." Id. at 363 . Costello had been indicted solely on the presentation of hearsay evidence, but the rationale of the majority opinion, and the concurring opinion of Justice Burton which would restrict the decision, $i d$. at 364 , indicate that the holding may be extended to situations in which the grand jury considers other forms of inadequate or incompetent evidence. See Lawn v. United States, 355 U.S. 339 (1958) (indictment may be valid even though based on evidence previously suppressed by court order). See also Notes, 65 YaLE L.J. 390 (1956), 62 HaRv. L. Rev. 111 (1948).

32. The principal argument against drawing an inference of guilt from invocation of the fifth amendment is that witnesses may find it desirable to invoke the privilege for reasons independent of their guilt or innocence. Griswold, The Fifrr AMrendarent TODAY 8-27, 56-68 (1955). But this argument is not without qualification. "It may well be, as has been said by high authority, that the Fifth Amendment protects against prosecution for crime, but it cannot protect against the obvious inference which would be takem by any thinking person. I would like to suggest again that in many circumstances that inference is not wholly warranted. A person who thinks a little further about the matter may find that there are many factors in some of these situations which must be taken into account before he reaches any conclusion about the inference he should take." Id. at 57 . (Emphasis added.) See also Griswold, The Fifth Amendment Today, 39 Maro. L. Rev. 191, 201 (1956): "I do not by any means take the position that a claim of privilege under the Fifth Amendment is an absolutely colorless act simply to be disregarded and nothing could happen when a person claims the privilege."

However, in Hook, Comaron Sense and the Fifth Amendment (1957), the author takes issues with the general thesis of Griswold's book. He states that a natural or reasonable inference in law is guided not by pure logic or abstract mathematical possibilities but by reliable generalizations concerning human behavior, psychology and customs. Even though the inference of guilt from the invocation of the privilege may be erroneous, it is legitimate, for to deny the inference is more often a mistake than to affirm it. Id. at 33-39. Because of the lesser requirement of certainty in the grand jury proceeding, see notes 29,31 supra, inference from the claim can be justified though it might not be at trial, see note 28 supra.

Justice Reed, writing for the majority in Adamson v. California, 332 U.S. 46, 56 (1947), thought it natural that the prosecution should bring out the strength of the evidence by commenting upon the defendant's failure to explain or deny. Justice Frankfurter, concurring, pointed out that sensible and just-minded men in important affairs of life deem it significant that a man remains silent when confronted with serious and responsible evidence against him which is within his power to contradict. Id. at 60 . 
suspect's refusal to explain can produce a reasonable doubt of innocence. ${ }^{33}$ An indictment based solely upon claim of the privilege, however, should be quashed as failing to establish probable cause. ${ }^{34}$

Thus, all persons summoned before a grand jury could be required to take the stand-and the anomalous distinction beween de facto and de jure defendants eliminated-provided constitutional freedom from compulsion was preserved. Currently, grand jury witnesses face secret examination without benefit of counsel or judicial supervision. ${ }^{35}$ To prevent the prosecutor from inducing a witness into unwitting relinquishment of his right not to reply, three minimal safeguards are needed. ${ }^{36}$ The prosecutor or foreman should inform each

See also Twining v. New Jersey, 211 U.S. 78, 82-83 (1908); State v. Grebe, 17 Kan. 458 (1877) ; Woronoff v. Mallon, 222 N.Y. 456, 468, 119 N.E. 102,-106 (1918) ; Williams op. cit. supra note 11, at 56-61; Rattner, supra note 28 , at 473; Reeder, supra note 27 , at 46 .

In Slochower v. Board of Education, 350 U.S. 551, 557 (1956), discussed note 30 supra, the Court condemned the practice of imputing a sinister meaning to the exercise of the fifth amendment privilege. However, the deprivation of due process of law found in Slochowerer lay in the failure to grant a hearing to determine the defendant's fitness to hold a teaching position. Seemingly, no constitutional right would be violated if invocation were deemed sufficient to call for such an inquiry, which in effect, is the proper significance of invocation of the privilege before the grand jury.

33. The inference of guilt does not arise from the invocation of the privilege alone but from the exercise of the right to remain silent in the face of unrefuted, incriminating evidence. See S WigMrore $\S \S 2273(4)-2276$ (a), at 433-44; Rattner, supra note 28 , at 474, 477.

34. Requiring that the prosecutor offer some extrinsic evidence of guilt would inhibit persecution of totally unimplicated parties and encourage independent search for evidence. The requirement could be enforced by quashing indictments resting on a witness' claim of constitutional protection and not supported by other evidence connecting accused with the alleged crime.

35. Sixth amendment right to counsel "in all criminal prosecutions" does not include the grand jury. Gilmore v. United States, 129 F.2d 199 (10th Cir.), cert. denied, 317 U.S. 631 (1942). Nor are witnesses allowed to bring counsel with them into the grand jury. In re Black, 47 F.2d 542, 543 (2d Cir. 1931) (drawing analogy to the rights of witnesses at trial); United States v. Blanton, 77 F. Supp. 812, 816 (E.D. Mo. 1948). No judge is present in the grand jury. Powell v. United States, 226 F.2d 269, 274 (D.C. Cir. 1955), though a judge charges the grand jurors when they are summoned and sworn, see Yankwich, Charge to Federal Grand Jury, in 19 F.R.D. 117 (1956). For a list of the persons who may be present before a grand jury, see FED. R. CRIM. P. 6(d).

A grand jury need not state in a subpoena to a witness either the subject matter of the investigation or the person against whom the inquiry is directed. Hale v. Henkel, 201 U.S. 43 (1905). The grand jury's range of inquiry is not limited by any predictable results of the investigation. Blair v. United States, 250 U.S. 273, 282 (1919); Howard v. United States, 182 F.2d 908 (8th Cir. 1950). The grand jury may pursue all ramifications of a particular inquiry. United States v. Johnson, 319 U.S. 503 (1943). "Broadly speaking, there are no restrictions to the investigating power of the grand jury in criminal matters provided it confines its activities to the purposes which led the court to call it into existence." Gold, supra note 5, at 395.

36. For discussion of prosecutor tactics attempting to elicit incriminatory replies, see United States v. Scully, 225 F.2d 113, 118 (2d Cir. 1955) (concurring opinion); Hooley 
witness of his constitutional protection and of the fact that testimony may subsequently be introduced at trial. ${ }^{37}$ In addition, courts should maintain their present strictures forbidding intimidation of grand jury witnesses. ${ }^{38}$ Finally, the doctrine of waiver-requiring a full explanation of an incriminating admission-should not be employed in grand jury proceedings. ${ }^{39}$ Applicable at trial to prevent concealment on cross-examination, ${ }^{40}$ the doctrine may entrap

v. United States, 209 F.2d 234, 235 (1st Cir. 1954); Pulford v. United States, 155 F.2d 944, 945-46 (6th Cir. 1946) ; United States v. Bell, 81 Fed. 830, 839-41 (C.C.W.D. Tenn. 1897) ; People v. Luckman, 164 Misc. 230, 297 N.Y. Supp. 616 (Sup. Ct. 1937).

37. On the desirability of warning, see United States v. Scully, stipra note 36, at 116 (arguing that de facto defendant should be able to quash his indictment if not informed of his privilege) (concurring opinion); Wood v. United States, 128 F.2d 265, 277 (D.C. Cir. 1942) ; United States v. Bell, supra note 36, at 838-39; see also United States v. Grossman, 154 F. Supp. 813, 817 (D.N.J. 1957) (de facto defendant may be interrogated "providing he is warned") ; Note, 34 Texas L. Rev. 641 (1956) ; Comment, 1956 WASH. U.L.Q. 373, 376; cf. United States v. Hoffa, 156 F. Supp. 495, 514-15 (S.D.N.Y. 1957) (warning gave de facto defendant full protection under the circumstances).

For the desirability of giving grand jury witnesses a full understanding that testimony can be used at trial, see United States v. Garnes, 156 F. Supp. 467, 469 (S.D.N.Y. 1957); see also United States v. Bell, supra note 36, at 838-39.

38. No fraud, deception or duress may be imposed upon a grand jury witness. See United States v. Klein, 247 F.2d 908 (2d Cir. 1957) ; United States v. Kimball, 117 Fed. 156, 163 (C.C.S.D.N.Y. 1902) ; United States v. Bell, 81 Fed. 830, 838-39 (C.C.W.D. Tenn. 1897).

In United States v. Garnes, supra note 37, an "ignorant" woman was told that if she did not testify, "a U.S. Marshal would be sent to get her." Although a motion to quash the indictment was denied because untimely, the defendant's testimony was excluded at trial because involuntary.

39. The doctrine of waiver, at first generally confined to adversary proceedings, see 8 WIGMORE $\$ 2276$, at 438-39 n.1, has been held applicable to the grand jury, United States v. St. Pierre, 132 F.2d 837, 840 (2d Cir. 1942). Under the doctrine, once an incriminating fact has been revealed, the witness "cannot invoke the privilege where response to the specific question ... would not further incriminate her." Rogers v. United States, 340 U.S. 367,373 (1951). Commentators have suggested two possible interpretations of Rogers. Either the privilege is waived whenever any fact has been admitted which a witness would have been privileged to conceal, or there is no waiver until the witness has admitted every material element of a crime. Note, The Privilege Against Self-Incrimination in the Federal Courts, 70 Harv. L. Rev. 1454, 1459 (1957) ; Comment, W Waiver of the Privilege Against Self-Incrimination, 52 Nw. U.L. Rev. 542, $544-45$ (1957). In United States v. Courtney, 236 F.2d 921 (2d Cir. 1956), the court adopted the broad interpretation of Rogers in refusing to find that a grand jury witness had waived the privilege when only one element of a crime had been admitted. For a general discussion of waiver, see $S$ WIGMORE $\$ \S 2275-78$; Note, The Privilege Against Self-Incrimination: The Doctrine of Waiver, 61 YALE L.J. 105, 108-09 (1952).

40. "[T] he usual justification of the doctrine [at trial] is that in its absence a witness for one side would be able, under questioning of friendly counsel, to present a distorted picture of the facts, while escaping the corrective of a vigorous cross-examination. Instead of ruling out such one-sided testimony altogether, courts preferred to use waiver to protect the rights of parties. They required disclosure of 'details' to place the testimony in a balanced perspective, and to ensure a fair trial." Note, 61 Y ALE L.J. 105, 108 (1952). 
even the well-informed witness and is inappropriate in an ex parte proceeding from which counsel are barred.41

Requiring that every grand jury witness undergo questioning with full comprehension of his rights and a fair opportunity to exercise them would substitute a uniform test of volition for superficial considerations of status. ${ }^{42}$

41. The rationale underlying the doctrine has no application to an ex parte proceeding. The balance of interest is not between the rights of an adverse party and those of a witness, but between the state's rights to information and the witness' right not to incriminate himself. See Note, 61 YALE L.J. 105, 109 (1952). Furthermore, witnesses are not allowed to bring counsel whose advice could prevent an inadvertent waiver of the privilege. See note 35 supra. To sacrifice the witness' rights in an $e x$ parte proceeding attacks the underlying purpose of the privilege-to prevent the state from forcing incrimination by abuse of the inquisitorial method. 8 WrGMORE $\$ 2251$. Justice Black, dissenting in Rogers v. United States, 340 U.S. 367, 375 (1951), discussed note 39 supra, stated that the witness before a grand jury had no intention of relinquishing her privilege against self incrimination by answering preliminary questions. Criticizing the majority opinion, he stated: "[T]oday's holding creates this dilemma for witnesses: On the one hand, they risk imprisonment for contempt by asserting the privilege prematurely; on the other, they might lose the privilege if they answer a single question. The Court's view makes the protection depend on timing so refined that lawyers, let alone laymen, will have difficulty in knowing when to claim it." Id. at 378. Compare United States v. St. Pierre, 128 F.2d 979 (2d Cir. 1942), with United States v. St. Pierre, 132 F.2d 837 (2d Cir. 1942), aff'd, 319 U.S. 41 (1943); cf. Powers v. United States, 223 U.S. 303, 314-16 (1912) (waiver at preliminary hearing).

United States v. Lawn, 115 F. Supp. 674 (S.D.N.Y. 1953), according a de jure defendant before the grand jury the rights of a defendant at trial, may not afford as great a protection as would at first appear. If a de jure defendant elects to testify in the grand jury, he may be held to have waived his privilege against self incrimination if trial rules are applicable. See note 13 supra. The question has not been decided.

English law does not recognize the doctrine of waiver and the witness may halt in his testimony and invoke the privilege at any point. Regina v. Garbett, 2 Car. \& K. 474, 495, 175 Eng. Rep. 196, 205 (N.P. 1847). For modern cases on the English rule, see 13 HaLsBURY, Laws of ENGLAND 730-33 (2d ed. 1934). Application of the English rule to the grand jury would prevent the inadvertent loss of a constitutional privilege, would not impair the function of the grand jury in determining probable cause, and would not be inimical to the policy underlying the doctrine of waiver.

42. A volition test was first developed with respect to a grand jury proceeding in United States v. Kimball, 117 Fed. 156, 163, 165 (C.C.S.D.N.Y. 1902) : "Compulsion is the antithesis of willingness. . . Any unlawful action by the district attorney, or by the jury, or other official, that should appear to have impaired the exercise of the free will of the witness in choosing whether he would testify, should be regarded as compulsion." For other definitions of volition, see United States v. Klein, 247 F.2d 908 (2d Cir. 1957) (testimony freely given, all things considered) ; Mulloney v. United States, 79 F.2d 566, 576 (1st Cir. 1935) (free opportunity to exercise rights); United States v. Grossman, 154 F. Supp. S13, 817 (D.N.J. 1957) (as long as witness is warned, irrelevant that he was marked for prosecution); see also United States v. Scully, 225 F.2d 113 (2d Cir. 1955) (whether witness was aware of his rights and if informed, would have testified differently). But sec concurring opinion of Judge Frank, id. at 117 (warning always necessary to insure voluntary testimony because improper to speculate if witness was aware of his rights or if he would have testified differently had he known them).

Two early cases developed a "voluntary test" for the admissibility of pre-trial statements. See Powers v. United States, supra note 41 , at 314 (statement at pre- 
Applying the test, courts would quash an indictment of any grand jury witness who did not voluntarily waive his constitutional privilege. ${ }^{43}$ This procedure would avert the danger of self incrimination by a person who was likely to forfeit his rights because he was unaware of them. ${ }^{44}$ Furthermore, admissions obtained from the uninformed or intimidated witness should be excluded at trial and in subsequent grand jury proceedings to preclude facile reindictment.45 These safeguards-together with a requirement that indictments rest at least in part on incriminating evidence other than a refusal to reply ${ }^{46}$-would assure

liminary hearing) ; Wilson v. United States, 162 U.S. 613, 624 (1896) (confession before commissioner). See also United States v. Block, 88 F.2d 618, 621 (2d Cir. 1937) (admitting at trial confession made in previous trial because the admission was "freely given, all things considered"). Courts have considered a variety of factors in determining whether statements made by a defendant were voluntary. See United States v. Klein, sutpra at 920-21 (witness was warned) ; Pulford v. United States, 155 F.2d 944, 948 (6th Cir. 1946) (education) ; United States v. Hoffa, 156 F. Supp. 495, 514 (S.D.N.Y. 1957) (witness had received advice of counsel before and during grand jury proceeding). For discussion of circumstances precluding a finding of voluntary waiver of right to counsel, see Johnson v. Zerbst, 304 U.S. 458 (1938).

In United States v. Hoffa, supra, the defendant, who had been warned of his privilege, attempted to have his indictment quashed on the ground that his testimony had been compelled. Refusing to extend the rule of United States v. Lawn, supra note 41, the court found that, "Hoffa clearly was not 'de facto' an accused' when called before the Grand Jury," $156 \mathrm{~F}$. Supp. at 514 , and had waived his privilege by failing to invoke it after being warned, id. at 510 . From the circumstances of the case, however, it would seem that Hoffa was implicated in the criminal activity under investigation and that this fact was known to the prosecutor. The court distinguished Lawn as applicable only to de jurc defendants, $i d$. at 514 n.4, and noted that Judge Frank's rule, in his concurring opinion in United States v. Scully, supra, had not been violated even if it were the law, since Hoffa had been warned. "Gauged by exacting and sensitive constitutional standards, the conduct of the United States Attorney and the Grand Jury recognized and respected the defendant's rights completely. The record shows clearly that he was not tricked nor imposed upon nor misled." Id. at 514. In light of all the circumstances, there could have been no compulsion. $I d$. at 515 .

43. See United States v. Lawn, 115 F. Supp. 674, 678 (S.D.N.Y. 1953). This should only be applied if a motion to quash is made prior to trial. If there has been conviction, the issue on appeal should be whether or not compelled evidence had been admitted at trial. See note 17 supra.

44. See note 37 supra; cf. United States v. Scully, 225 F.2d 113, 117 (2d Cir. 1955) (concurring opinion).

45. The rule excluding coerced confessions and leads obtained therefrom at trial is established in Weeks v. United States, 232 U.S. 383 (1914), and McNabb v. United States, 318 U.S. 332, 344-46 (1943). For application to evidence given before the grand jury, see United States v. Lawn, 115 F. Supp. 674, 678 (S.D.N.Y. 1953) ; see also In re Fried, 161 F.2d 453 (2d Cir. 1947) (suppressing involuntary testimony in advance of trial).

If testimony is compelled in one grand jury investigation, it should not be introduced in a subsequent hearing to obtain an indictment. See United States v. Giglio, 232 F.2d 589, 595 (2d Cir. 1956) (implying that "tainted" evidence would be grounds for dismissal of an indictment). But see Lawn v. United States, 355 U.S. 339 (1958) (implying that reindictment valid even when based on "tainted" evidence).

46. See notes 33-34 supra. 
meaningful fifth amendment protection. ${ }^{47}$ Yet, within this framework, effective grand jury examination of all summoned parties could be achieved.

47. An even greater though more radical protection for a witness would permit counsel to accompany him into the grand jury room, to sit by him as at a congressional hearing and to advise him on the exercise of the privilege against self incrimination. For general discussion, see Beaney, Right to Counsel in American Courts (1955); Becker \& Heidelbaugh, Right to Counsel in Criminal Cases, 28 Notre Dane LAw. 351 (1953) ; Fellman, The Constitutional Right to Connsel in Federal Courts, 30 NEB. L. Rev. 559, 587-\$9 (1951) ; Fellman, Right to Counsel Under State Law, 1955 WIs. L. Rev. 281, 292.

For the view that the presence of counsel would violate the secrecy of grand jury proceedings, see Gold, Privilege Against Self-Incrimination in Federal Grand Jury Proceedings, 24 TEarp. L.Q. 395, 405 (1951). A lawyer trained in investigation and trial work might also be able to discover the prosecutor's case against his client from the nature of the interrogation. Excluding counsel for this reason, however, is inconsistent with the pretrial discovery provisions of $F_{E D}$. R. CRrar. P. 7 (f), 16, and the right to employ counsel at arraignment, id. 5 (e). If the lawyer's role before the grand jury could be restricted to advising the witness as to his privilege against self incrimination, thus avoiding delay and impairment of grand jury proceedings resulting from objections on the basis of relevancy, jurisdiction, form of questions and the like, the position of prosecutor and witness would be equalized both before as well as after indictment. See Orfield, Discovery and Inspection in Federal Criminal Proceditre, 59 W. VA. L. REv. 221 (1957). Because of the freewheeling nature of the grand jury, however, counsel doubtless will continue to be excluded in the future. 